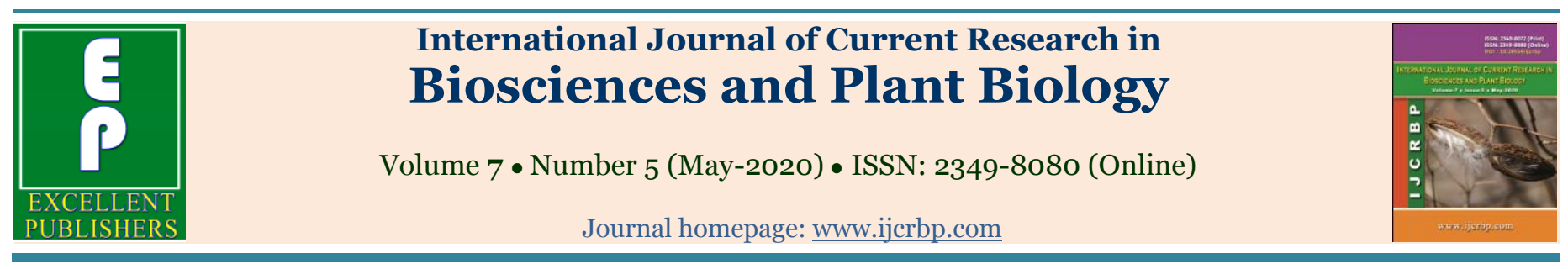

\title{
Molecular characterization of Pterocarpus erinaceus Poir. (Fabaceae) of Côte d'Ivoire using RAPD markers
}

\author{
Koudougnon Alice Estère GOBA ${ }^{1 *}$, Léonie Clémence KOUONON1, \\ Kouamé Guillaume KOFFI', Adjoumani KOFFI², Bi Irié Ghislain TRE \\ and Raoul Sylvère SIE1
}

\begin{abstract}
1Université Nangui Abrogoua, Pôle de recherche Production Végétale, 02 BP 801 Abidjan 02, Côte d’Ivoire ${ }^{2}$ Ecole Normale Supérieure d'Abidjan, o8 BP 10 Abidjan 08, Côte d'Ivoire

*Corresponding author; e-mail: aegoba3@yahoo.fr / +22508 763418
\end{abstract}

\begin{tabular}{ll}
\hline Article Info & ABSTRACT \\
\hline $\begin{array}{l}\text { Date of Acceptance: } \\
\text { 28 April 2020 }\end{array}$ & $\begin{array}{l}\text { Over-exploitation of Pterocarpus erinaceus, a woody species of savannah, endemic to } \\
\text { West Africa, negatively impacts the sites of protected areas in Côte d'Ivoire. This study } \\
\text { aims to characterize the genetic diversity of six sites using six RAPD markers in order to } \\
\text { Date of Publication: } \\
\text { o6 May 2020 }\end{array}$ \\
$\begin{array}{l}\text { contribute to the implementation of optimal management and conservation plans for } \\
\text { this species. Genomic DNA was extracted from fragments of leaflets from 144 trees }\end{array}$ \\
following the CTAB protocol. After DNA amplification, the number of alleles ranged \\
from 1.33 to 8.17 and the effective number of alleles ranged from 1.09 to 3.94 per site.
\end{tabular}

\section{Introduction}

Galloping population growth with the corollary of anthropogenic activities (extensive agriculture, gold panning and uncontrolled exploitation of energy and timber) is leading to the loss of forest genetic resources (MEDD, 2016). In Côte d'Ivoire, forest areas have decreased from 16 million hectares in the early 20th century to 3.4 million hectares in 2015, i.e. an average rate of disappearance of more than 200,000 hectares per year (MINEF, 2018). The situation has become more alarming in recent decades because the pressure has increased on the rare woody species of savannahs with high socio-economic potential (BNETD, 2015). These include trees of high economic value such as Afzelia africana Sm. ex Pers, Lophira lanceolata Tiegh. ex Keay and Pterocarpus erinaceus Poir. (FAO, 2002).

Pterocarpus erinaceus, commonly called African rosewood, Senegalese rosewood, African teak, is a 
multi-purpose species, endemic to the GuineoSudanian and Sudano-Sahelian savannahs (Arbonnier, 2004). In Côte d'Ivoire, the species is found from west to east, throughout the pre-forest zone (Guinean savannah), up to the northern limit (Sudanese savannah). African rosewood is an excellent timber, service and carbonization wood (Segla et al., 2015). Leaves, bark and roots of the species contain chemicals such as alkaloids, flavonoids, saponins, anthracenes and catechic tannins (Dedehou et al., 2016; Ouédraogo et al., 2017). These characteristics make it a plant widely used in the traditional pharmacopoeia to cure several ailments including anaemia, cough, dysentery, malaria and childhood fever because these organs possessed local anti-inflammatory effect and antioxidant properties (Segla et al., 2015 ; Ouédraogo et al., 2017). Furthermore, $P$. erinaceus is one of the woody species in the north of the country most commonly used in cattle feed (Silué et al., 2014). For all these uses, the species is exploited in an anarchic and uncontrolled manner, even in natural protected areas in West Africa and particularly in Côte d'Ivoire, without respecting management principles (CITES, 2015; Adjonou et al., 2019). Therefore, african rosewood is the most heavily traded tropical hardwood in the world (Dumenu, 2019). Côte d'Ivoire rises to $3^{\text {rd }}$ position among West African countries where the exploitation of the species has increased over the last decade (CITES, 2017). From January 2012 to September 2013, more than $6,000 \mathrm{~m}^{3}$ of African rosewood were exported to China from Côte d'Ivoire (ONU, 2014).

Given the growing market demand for African rosewood and the need to conserve ecosystems, international community is mobilizing. In Côte d'Ivoire, a regulatory framework was formulated, through decree $\mathrm{N}^{\circ}$ 2013-508 of 25 July 2013 (MINEF, 2013), prohibiting the exploitation, cutting, transporting, marketing and exportation of $P$. erinaceus, in addition to international legislation (CITES, 2017). It is therefore important to find mechanisms for sustainable ecosystem management based on genetic aspects, which are prerequisite for forest management decisions. The study of genetic diversity has the advantage of contributing to the advancement of conservation biology, population and community ecology and evolutionary biology. To this end, population genetics provides estimators of genetic parameters which can provide information on effective population size, gene flow or differentiated gene pools (Diniz-Filho and De Campos-Telles, 2002) allowing the development of short- and long-term management plans (Song et al., 2005; Watts et al., 2005).

Different methods of assessing genetic variability from molecular markers or DNA have been widely used. Among the various markers used, random amplified polymorphic DNA (RAPD) is the most popular of the DNA-based markers (Jena et al., 2004). These markers have several advantages over other DNA markers because they are less technically demanding, relatively low cost, use small amounts of target DNA and are a quick method of providing information from a large number of loci, especially in species for which no study has been carried out before (Fontaine et al., 2004). Studies on the genetic diversity of Pterocarpus species have widely used the RAPD technique. Amri and Mamboya (2012) used 11 RAPD markers to assess the genetic diversity of $P$. angolensis DC. in six natural sites in eastern Tanzania. These markers revealed $75.3 \%$ polymorphism. Jyothi et al. (2015) evaluated the molecular variability of six sites of $P$. santalinus L. originating in India using 20 RAPD markers by identifying two genetic groups within the sites studied with a level of genetic similarity of $75 \%$. Sulistyawati and Widyatmoko (2017) conducted a genetic diversity analysis of six sites of $P$. indicus Willd in Indonesia with RAPD markers. This study made it possible to highlight $99 \%$ of polymorphism with 12 RAPD primers. However, no molecular studies have been performed on $P$. erinaceus. This study of the genetic diversity of $P$. erinaceus is being carried out with the aim of producing reliable data on the genetic variability and structure of this species using RAPD markers in order to develop an optimal management plan and conservation of species resources in Côte d'Ivoire.

\section{Materials and methods}

\section{Collection of plant material}

Data collection on $P$. erinaceus trees was carried out in tree agro-ecological savannah zones (Guinean, sub-Sudanian and Sudanian (FAO, 2002)) in Cote d'Ivoire. Leaflet fragments from 144 
trees were collected and dehydrated with silica gel. Leaflet fragments were collected from six sites near the towns of Biankouma, Bondoukou, Bouna, Ferkessédougou, Odienné and Zuénoula (Table 1).

Table 1. Geographic positions and type of vegetation in the sites of Pterocarpus erinaceus sampled

\begin{tabular}{llllll}
\hline Cities & Sites & Types of savannah & $\begin{array}{l}\text { Longitude } \\
\text { (d.ddddd) }\end{array}$ & $\begin{array}{l}\text { Latitude } \\
\text { (-d.ddddd) }\end{array}$ & $\begin{array}{l}\text { Altitude } \\
\text { (m) }\end{array}$ \\
\hline Biankouman & Yalo & & 7.90491 & -7.84064 & 502 \\
Zuenoula & Moyenne Marahoué & Guinean savannah & 7.60971 & -6.23603 & 282 \\
Odiénné & Kahanso & Sub-Sudanese & 9.28575 & -7.62309 & 426 \\
Bondoukou & Kouassi-Ndawa & savannah & 8.11628 & -2.90282 & 361 \\
Ferkessédougou & Ouarigué & Sudanese savannah & 9.61480 & -4.97490 & 369 \\
Bouna & Téguirdouo & & 9.61237 & -4.97574 & 373 \\
\hline
\end{tabular}

\section{DNA extraction, quantification and amplification condition}

The extraction protocol used is that of Doyle and Doyle (1987) modified by Azmat et al. (2012) with new modifications in our study. This protocol is based on Cethyl trimethylammonium bromide (CTAB). About $30 \mathrm{mg}$ of dehydrated leaflet fragments from each tree were crushed in sterile mortars after evaporation of the liquid nitrogen. The powder was diluted in $700 \mu \mathrm{l}$ of extraction buffer previously heated in a water bath to $65^{\circ} \mathrm{C}$ and the mixture was inverted in a $2 \mathrm{ml}$ Eppendorf tube. The contents of each tube were mixed by inversion and vigorously vortexed before being incubated in a water bath for $1 \mathrm{~h} 30 \mathrm{~min}$ at $65^{\circ} \mathrm{C}$, meanwhile contents were homogenized by inversion at least three times. An equal volume of $700 \mu \mathrm{l}$ of chloroform isoamyl alcohol (24:1) at $4^{\circ} \mathrm{C}$ was added to the contents of the tube and the mixture was centrifuged at 10,000 rpm for $15 \mathrm{~min}$ at room temperature. The aqueous phase was transferred to a new tube with $500 \mu$ of chloroform isoamyl alcohol (24:1) at $4^{\circ} \mathrm{C}$, mixed by inversion and centrifuged again under the same conditions. The aqueous phase was transferred to a new tube and then isopropanol at $-20^{\circ} \mathrm{C}$ was added to precipitate DNA before placing the tubes in the freezer at $-20^{\circ} \mathrm{C}$ for $20 \mathrm{~min}$. Cooled tubes were centrifuged at 13,000 rpm for $15 \mathrm{~min}$. The DNA pellet, obtained at the bottom of the tube after gently emptying the tube, is washed twice with 500 $\mu \mathrm{l}$ of $70 \%$ ethanol by centrifugation (13,000 rpm for $15 \mathrm{~min}$ ), then the washed DNA pellet is dried in an oven $\left(37^{\circ} \mathrm{C}\right)$ before being suspended in $100 \mu \mathrm{l}$ TE buffer. Five microliters $(5 \mu \mathrm{l})$ of RNase was added and the mixture was incubated at $37^{\circ} \mathrm{C}$ for 2 $\mathrm{h}$ to remove all traces of RNA before storing the DNA at $-20^{\circ} \mathrm{C}$ until use.
The DNA concentration of all samples was determined using a spectrophotometer, Nanodrop ND-1000 (NanoDrop Technologies, Inc.). The acceptable absorbance ratio for pure DNA was 1.7 to 1.9. The quality and integrity of the DNA was confirmed by migration into a 1\% agarose gel and compared with a size standard (Eurogentec smart ladder Ref. MW170010).

RAPD primers used have been selected on those used on Pterocarpus angolensis (Amri and Mamboya, 2012) and P. indicus (Delos-Reyes et al., 2016). Twenty RAPD primers provided by Promega (PROMEGA, Madison, WI USA) and tested on a sample of 12 individuals of $P$. erinaceus from six different sites, only six polymorphic primers were selected. Amplification was made in a reaction volume of $30 \mu \mathrm{L}$ containing $25 \mu \mathrm{L}$ of the PCR mixture and $5 \mu \mathrm{L}$ of DNA diluted at $20 \mathrm{ng} / \mu \mathrm{L}$. For each sample and each primer, the PCR mixture contained $16.14 \mu \mathrm{L}$ of sterile water, $3 \mu \mathrm{L}$ of $5 \mathrm{x}$ coloured buffer, $3 \mu \mathrm{L}$ of $5 \mathrm{x}$ uncoloured buffer, $1.8 \mu \mathrm{L}$ of $25 \mathrm{mM} \mathrm{MgCl}_{2}, 0.51 \mu \mathrm{L}$ of $10 \mathrm{mM}$ dNTP, $0.3 \mu \mathrm{L}$ of $20 \mathrm{mM}$ primer and $0.25 \mu \mathrm{L}$ of 5 units of Taq polymerase (PROMEGA, Madison, WI USA). The GeneAmp PCR System 9700 thermal cycler (Applied Biosystems, USA) was used to carry out PCR reactions of a double amplification of 47 cycles. The amplification conditions are : a first denaturation at $94^{\circ} \mathrm{C}$ for 4 min followed by 47 cycles of denaturation at $93^{\circ} \mathrm{C}$ for $20 \mathrm{sec}$, hybridization at $36^{\circ} \mathrm{C}$ for $40 \mathrm{sec}$ and elongation at $72^{\circ} \mathrm{C}$ for $1 \mathrm{~min}$. The reaction ends with a final elongation phase at $72^{\circ} \mathrm{C}$ for $4 \mathrm{~min}$ and a cooling phase at $4^{\circ} \mathrm{C}$. Amplification was repeated at least twice, and only reproducible bands that showed clear profiles were considered. Amplified bands were separated by migration on $0.8 \%$ agarose gels with a $1 \mathrm{~kb}$ DNA ladder (PROMEGA, Madison, WI USA) and revealed using Suber Safe as a dye. 


\section{Data analysis}

Clearly identifiable and reproducible amplified DNA bands were entered into a binary matrix coded as follows: 1 for presence and o for absence.

For each primer, the total number of bands, the number of polymorphic bands and the percentage of polymorphic loci were estimated. For each site, intra-population diversity (number of alleles $(\mathrm{Na})$, number of efficient alleles $(\mathrm{Ne})$, Shannon index $(I)$ and Nei diversity $(h)$ ) were calculated using GenAlEx version 6.5 software (Peakall and Smouse, 2012).

Genetic differentiation among sites was estimated using the unbiased genetic distances of Nei (1972). In order to determine the degree of genetic differentiation among subpopulations $\left(\Phi_{P T}\right)$, a hierarchical analysis of molecular variance (AMOVA) was conducted using GenAlEx 6.502 software (Meirmans, 2006). A dendrogram based on the UPGMA algorithm (Sneath and Sokal, 1973) was constructed from Nei's genetic distance matrix using the Phylip module (Felsentein, 2004).

Genetic groups were established using STRUCTURE software by applying the model with " admixture » and the option of independent allelic frequencies. This method evaluates the probability of each individual belonging to a fictitious population and the most likely number of $\mathrm{K}$ fictitious populations. Ten independent simulations were carried out for each value of $\mathrm{K}$ (varying from 1 to 10 ). The best $\mathrm{K}$ was evaluated according to the method of Evanno et al. (2005). A tree is assigned to a group when its probability of belonging to that group is greater than 0.70 (Evanno et al., 2005). When this assignment probability is lower than 0.7 , individuals are considered as «admixed": the genotype then comes from recombination among several genetic groups.

\section{Results}

\section{Polymorphism of markers}

Of the 20 RAPD primers tested on 12 individuals of $P$. erinaceus from the six sites (two individuals per site), five generated no bands and seven generated changing bands with only a few individuals. Of the eight primers with reproducible and intense bands, six generated polymorphic bands on a larger number of individuals. Finally, six primers were used to analyze the diversity and genetic structure of African rosewood.

A total of 60 bands were generated from the six RAPD primers on 70 trees out of a total of $144 P$. erinaceus individuals. The number of bands per individual ranged from 8 to 11 (8 for KFP-02, 9 for KFP-24, 10 for KFP-08 and 11 for KFP-05, OPA-02 and OPN-06) with an average of 10 bands per individual per primer (Table 2). All the six markers were polymorphic. The rate of polymorphism ranged from $66.67 \%$ (KFP-24) to 100\% (KFP-05, KFP-08, OPA-02 and OPN-06), with an average of $90.28 \%$. Fig. 1 illustrates an example of genomic profiles of a few individuals selected at random from the six sites of $P$. erinaceus. The size of the amplification products (bands) ranges from 300 to $3400 \mathrm{bp}$.

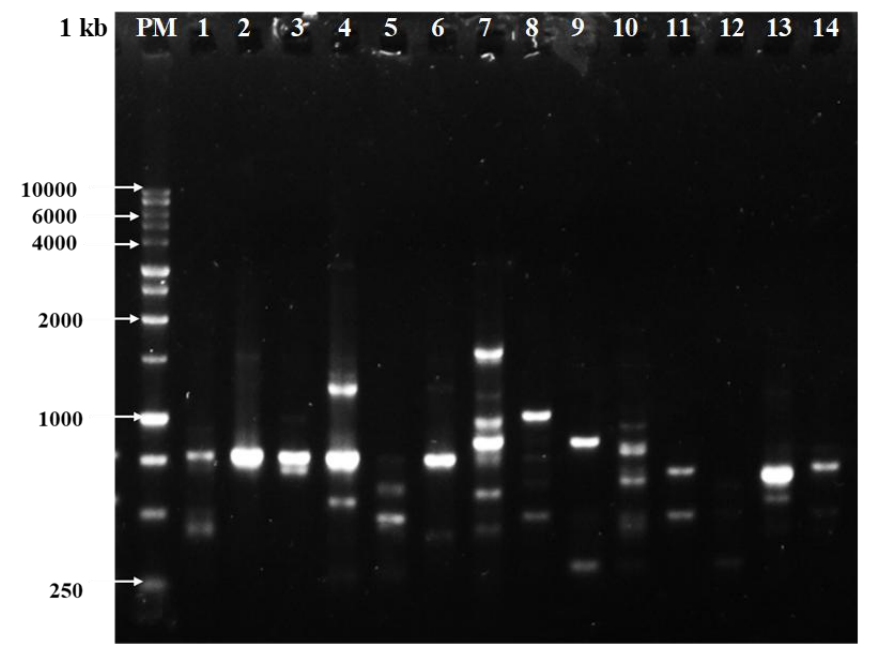

Fig. 1: Example of genomic DNA polymorphism of Pterocarpus erinaceus detected by the RAPD primer OPN-06 (PM: molecular weight marker, 1 to 14: DNA samples used).

\section{Intra-population genetic diversity}

Intra-population genetic diversity parameters generated for each site are summarized in Table 3. The mean number of alleles $(\mathrm{Na})$ per site ranged from $1.33 \pm 0.21 / 0.33$ for the Kouassi-Ndawa and Ouarigué to $8.17 \pm 1.14$ for Yalo, with a mean value of $4.25 \pm 0.59$. The effective number of alleles $(\mathrm{Ne})$ varied from $1.09 \pm 0.06$ for Kouassi-Ndawa to 3.94 \pm 1.41 for Moyenne Marahoué with a mean value of $2.33 \pm 0.35$. The mean diversity index for Shannon 
(I) was estimated to $0.78 \pm 0.13$ ranging from 0.13 \pm 0.08 for Kouassi-Ndawa to $1.55 \pm 0.25$ for Yalo. The mean genetic diversity $(h)$ observed in the six sites of $P$. erinaceus was $0.35 \pm 0.05$. Moyenne
Marahoué and Yalo were the most diverse with $0.64 \pm 0.06$ / 0.09 while Kouassi-Ndawa with a diversity index of $0.07 \pm 0.05$ was the least diverse.

Table 2. Number of bands, percentage of polymorphism and band size range revealed by the RAPD markers used.

\begin{tabular}{llllll}
\hline Primers & $\begin{array}{l}\text { Nucleotide sequence } \\
\text { of primers }\end{array}$ & $\begin{array}{l}\text { Total no. of } \\
\text { bands }\end{array}$ & $\begin{array}{l}\text { No. of } \\
\text { polymorphic } \\
\text { bands }\end{array}$ & $\begin{array}{l}\text { Polymorphism } \\
\text { (\%) }\end{array}$ & Bands size \\
\hline KFP 02 & CGTCCGTCAG & 8 & 6 & 75 & $333-3000$ \\
KFP 05 & CCTGGCGAGC & 11 & 11 & 100 & $313-1667$ \\
KFP 08 & ACGCGCTGGT & 10 & 10 & 100 & $350-2000$ \\
KFP 24 & ACTCGTAGCC & 9 & 6 & 66.67 & $438-3400$ \\
OPA 02 & TGCCGAGCTG & 11 & 11 & 100 & $313-2834$ \\
OPN 06 & GAGACGCACA & 11 & 11 & 100 & $300-2000$ \\
\hline Moyenne & & 10 & 9 & 90.28 & \\
\hline
\end{tabular}

Table 3. Intra-population diversity indices ( \pm standard deviation) of the six sites of Pterocarpus erinaceus analyzed.

\begin{tabular}{lccccc}
\hline Sites & $\mathbf{N}$ & $\boldsymbol{N a}$ & $\boldsymbol{N e}$ & $\boldsymbol{I}$ & $\boldsymbol{h}$ \\
\hline Yalo & 17 & $8.17 \pm 1.14$ & $3.75 \pm 0.91$ & $1.55 \pm 0.25$ & $0.64 \pm 0.09$ \\
Moyenne Marahoué & 14 & $7.33 \pm 1.02$ & $3.94 \pm 1.41$ & $1.50 \pm 0.21$ & $0.64 \pm 0.06$ \\
Kahanso & 8 & $2.33 \pm 0.62$ & $1.65 \pm 0.33$ & $0.50 \pm 0.23$ & $0.27 \pm 0.13$ \\
Kouassi-Ndawa & 8 & $1.33 \pm 0.21$ & $1.09 \pm 0.06$ & $0.13 \pm 0.08$ & $0.07 \pm 0.05$ \\
Téguirdouo & 17 & $5 \pm 1.61$ & $2.29 \pm 0.77$ & $0.86 \pm 0.34$ & $0.36 \pm 0.14$ \\
Ouarigué & 6 & $1.33 \pm 0.33$ & $1.26 \pm 0.26$ & $0.17 \pm 0.17$ & $0.10 \pm 0.10$ \\
Moyenne & 70 & $4.25 \pm 0.59$ & $2.33 \pm 0.35$ & $0.78 \pm 0.13$ & $0.35 \pm 0.05$ \\
\hline
\end{tabular}

$\mathrm{N}$ : sample size; $N a$ : number of alleles; $N e$ : number of effective alleles; I: Shannon diversity index and $h$ : Nei genetic diversity.

\section{Distribution of genetic diversity among sites and agro-ecological savannah zones}

The hierarchical analysis of molecular variance (AMOVA) revealed that $7 \%$ of the genetic variation is attributable to the difference among savannah types $\left(F_{S T}=0.074\right)$. The difference among sites generated $11 \%$ of the genetic diversity $\left(F_{S T}=0.118\right)$ and the largest portion of genetic variation, $82 \%$, was found to reside within sites $\left(F_{S T}=0.183\right.$; Table 4). The genetic differentiation among sites in the three agro-ecological entities considered is significantly different from zero $(\mathrm{p}=0.001)$. It was moderate $\left(F_{S T}\right.$ value between 0.05 and 0.15$)$ among types of savannah and among sites. However, genetic differentiation is important $\left(F_{S T}\right.$ value between 0.15 and 0.25 ) within the sites.

To assess phyletic relationships among sites, individual RAPD haplotypes were generated to estimate genetic distances among $P$. erinaceus sites. The distances calculated are low and range from 0.030 to 0.117 (Table 5). The closest sites are Kouassi-Ndawa and Ouarigué (o.030), then Kouassi-Ndawa and Kahanso (o.038). Conversely, Moyenne Marahoué is the furthest site and equidistant from Kouassi-Ndawa and Yalo (o.115) and to a lesser extent Téguirdouo (o.111).

Table 4. Distribution of genetic variation according to the analysis of molecular variance (AMOVA) on PCR-RAPD data at different phytogeographic levels (savannah type and sites).

\begin{tabular}{lllllll}
\hline S ources & df & SSD & MS & \% Variance & $\boldsymbol{F}_{\boldsymbol{S T}}$ & $\boldsymbol{p}$ \\
\hline Among savannah & 2 & 71.573 & 35.786 & 7 & 0.074 & 0.001 \\
Among sites & 3 & 56.141 & 18.714 & 11 & 0.118 & 0.001 \\
Within sites & 64 & 492.015 & 7.688 & 82 & 0.183 & 0.001 \\
\hline
\end{tabular}

df: degree of freedom; SSD: sum of squares of the deviations; MS: mean squares; $F_{S T}$ : coefficient of differentiation;

$P$ : probability associated with the estimated $F_{S T}$ value after 1000 resamples. 
Table 5. Pairwise genetic distances of Nei among the six sites of Pterocarpus erinaceus.

\begin{tabular}{|c|c|c|c|c|c|c|}
\hline Sites & Yalo & $\begin{array}{l}\text { Moyenne } \\
\text { Marahoué }\end{array}$ & Kahanso & $\begin{array}{l}\text { Kouassi- } \\
\text { Ndawa }\end{array}$ & Téguirdouo & Ouarigué \\
\hline Yalo & - & & & & & \\
\hline Moyenne Marahoué & 0.117 & - & & & & \\
\hline Kahanso & 0.089 & 0.095 & - & & & \\
\hline Kouassi-Ndawa & 0.115 & 0.117 & 0.038 & - & & \\
\hline Téguirdouo & 0.111 & 0.082 & 0.049 & 0.045 & - & \\
\hline Ouarigué & 0.092 & 0.074 & 0.049 & 0.030 & 0.042 & - \\
\hline
\end{tabular}

The dendrogram based on the UPGMA method, constructed from Nei's genetic distances matrix, highlighted the phyletic relationships among $P$. erinaceus sites (Fig. 2). This dendrogram revealed three genetic groups. The first group consists of four sites. The maximum genetic distance among pairs of sites within this group is less than 0.050 (Kouassi-Ndawa, Ouarigué, Kahanso and Téguirdouo).

The second group is composed solely of trees from Moyenne Marahoué. The minimum genetic distance between Moyenne Marahoué and group I is 0.074 while the maximum is 0.117 . The third group consists of trees from Yalo. The genetic distance between Yalo (group III) and Moyenne Marahoué (group II) is 0.117 . The minimum distance between Yalo and group I is 0.089 and the maximum is 0.115 .

\section{Structuring of genetic diversity in Pterocarpus erinaceus}

Bayesian analysis based on the allelic frequencies of the different individuals was performed. The maximum value of $\Delta \mathrm{K}$ was obtained with $\mathrm{K}=3$, suggesting the existence of three genetic groups (Fig. 3). Group I, represented by blue histograms, is observed in overall sites. It is the majority group of all genotypes and has the widest geographic distribution. Group II, represented by green histograms, is present only in Moyenne Marahoué, when group III, represented by red histograms, is mainly present in Yalo.

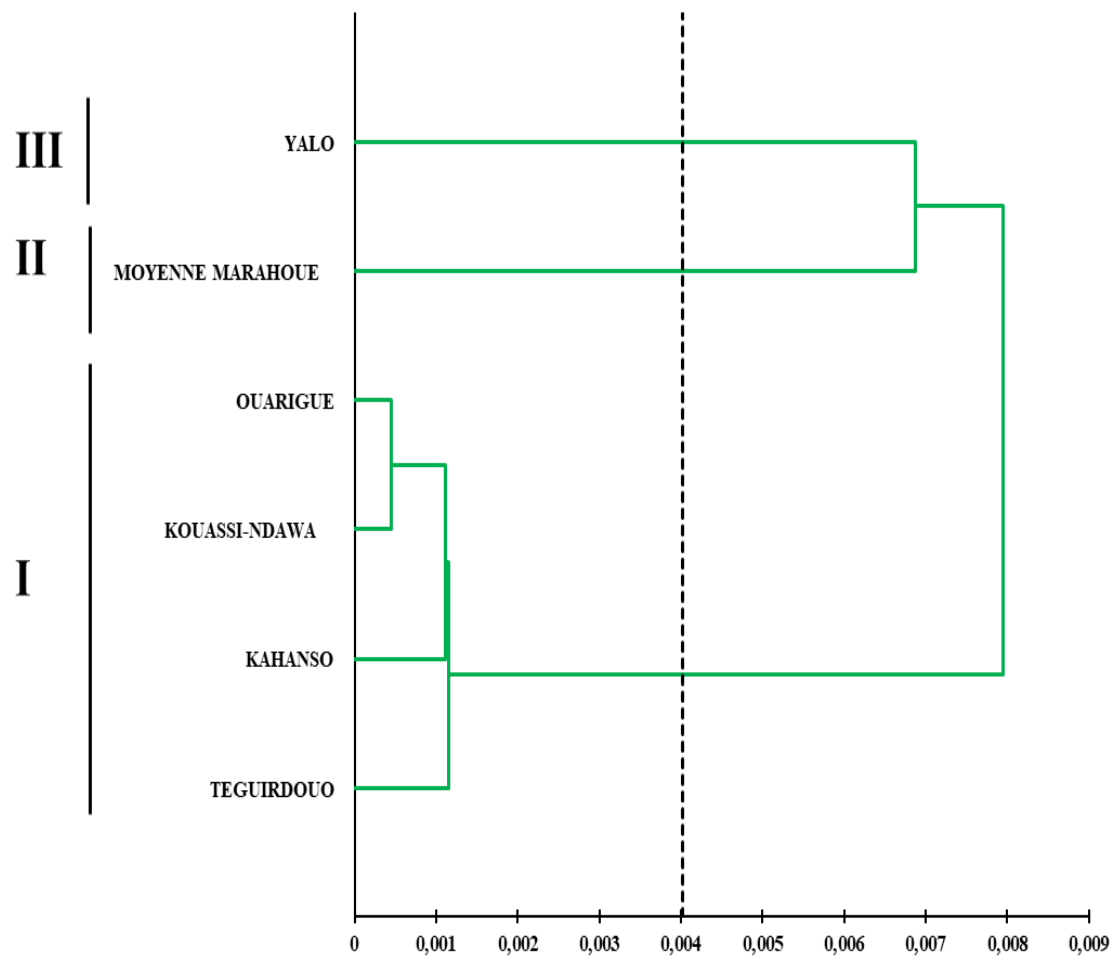

Fig. 2: Dendrogram based on the UPGMA method showing the relationships among the six sites of Pterocarpus erinaceus using RAPD markers. I: group 1; II: group 2 and III: group 3 . 


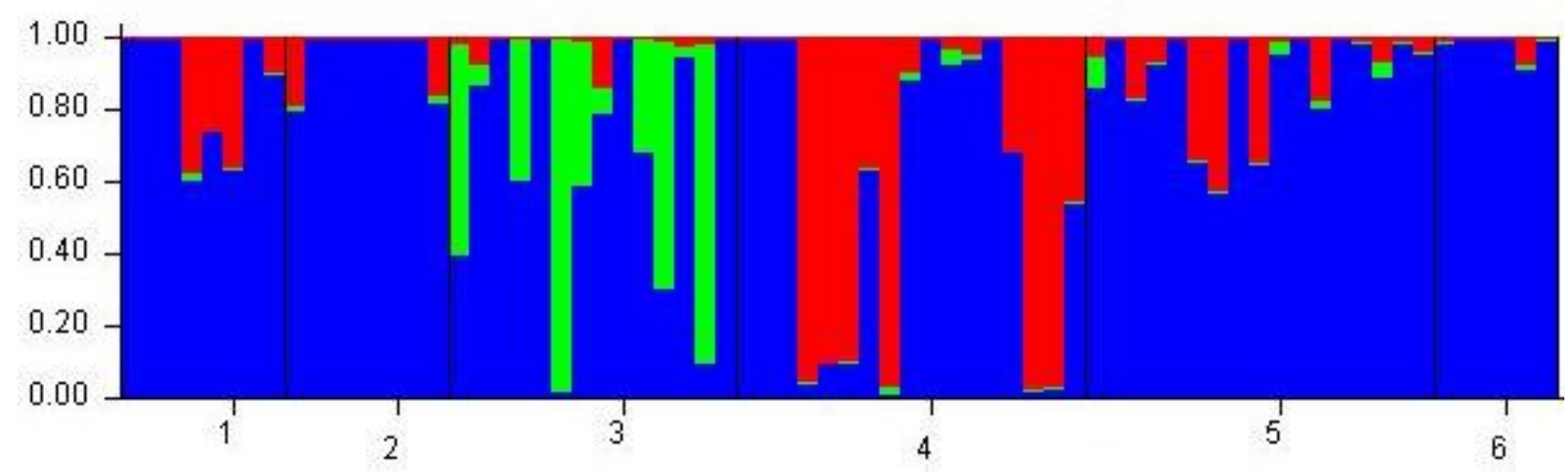

Figure 3: Histogram for assigning individuals to genetic groups based on the allele frequencies of RAPD genotyping of trees from the six sites of Pterocarpus erinaceus. The abscissa axis corresponds to the different populations (1: Kahanso, 2: Kouassi-Ndawa, 3: Moyenne Marahoué, 4: Yalo, 5: Téguirdouo and 6: Ouarigué), while the ordinate axis reflects the probability of membership of a tree in a gene pool $(\mathrm{K}=3)$. Each color represents a genepool. An individual is represented by a vertical bar with proportions indicating the portion of each genetic group in the genotype of the individual.

\section{Discussion}

\section{Polymorphism of markers}

The RAPD primers used in this study were found to be useful for the study of the genetic diversity of $P$. erinaceus even though they are not speciesspecific. Indeed, amplification by RAPD markers is rapid, relatively simple to perform and requires only a small amount of genomic DNA without prior information on the genomic sequence to be analyzed. The main drawbacks of using these markers were their dominant mode of detection and no guaranteed reproducibility. Nevertheless, dominant markers have been widely used for studies of genetic variability and varieties identification within several species (Sourou, 2017; Indu et al., 2019). In this study, reproducibility was ensured by repeating amplifications at least twice, and only those bands which were reproducible and showed clear profiles were selected. Of the 20 primers tested, six (i.e. 30\%) were found to be usable. The percentage of primers used that produced interpretable profiles for the analysis of genetic diversity then seems to depend on the adaptability of the primers to the species studied and experimental conditions. The polymorphism generated by the RAPD-PCR technique is due to substitutions, deletions/insertions of nucleotide bases in the regions of complementary bases to the primers (Semagn et al., 2006). A total of 60 reproducible bands of which 55 polymorphic bands were obtained corresponding to $90.28 \%$ polymorphism. This polymorphism is much higher than those obtained from other woody species: 65,43 \% in Parkia biglobosa (Amusa et al., 2014) and $78.12 \%$ in Tectona grandis Lf (Chaudhari et al., 2018). Therefore, the use of these RAPD markers to study the genetic diversity of the six sites of $P$. erinaceus is judicious.

\section{Characterization of genetic diversity of Pterocarpus erinaceus}

AMOVA revealed that the mean value of genetic diversity within $P$. erinaceus sites was 0.35 . According to Nei (1987), 0.35 value, which is between 0 and 0.4 , is in the low genetic diversity category. The low value of genetic diversity may be due to the small sample size (70 trees) due to the strong exploitation pressure on $P$. erinaceus in their natural distribution areas. Indeed, African rosewood trees are constantly being cut down by local populations for various uses (timber, therapeutic products and fodder). This anarchic harvesting would, in part, lead to a loss of $P$. erinaceus genetic resources, whereas genetic diversity is an important parameter because it is synonymous to potential ecological adaptation and micro-evolution. Overexploitation of $P$. erinaceus therefore threatens the genetic diversity of this species and could limit the ecological and evolutionary development of the remaining populations in Côte d'Ivoire. However, the mean 
genetic diversity observed $(h=0.35)$ is high compared to that obtained by Phuong et al. (2019) in Pinus kwangtungensis $(h=0.25)$ and by Sulistyawati and Widyatmoko (2017) in P. indicus $(h=0.20)$. The genetic diversity values obtained in our study suggest that $P$. erinaceus populations studied show good levels of diversity.

The portion of intra-population genetic diversity is $82 \%$. It is higher than genetic diversity imputable to the variation in allelic frequency among sites (11\%). Moyenne Marahoué and Yalo (Guinean savannah) showed a good level of diversity. Intrapopulation genetic diversity is the diversity that is expressed in a site due to the genetic variations among individuals in this population. This intrapopulation variability is greater than that reported by Sourou (2017) in Haematostaphis barteri populations in Benin. The stability and survival of plant species, such as trees, in constantly disturbed environments depend on the genetic diversity available. $P$. erinaceus populations with an high level of genetic variation are valuable because they provide a diverse gene pools from which genetic conservation and breeding programs can be established. In-situ conservation of this species is therefore useful to preserve intra-population diversity and the process of adaptation of individuals to changing environmental conditions. The large amount of intra-population variation observed in these sites suggests that intensive sampling within a few sites for reforestation or conservation would capture much of the diversity within the species. To produce seedlings for reforestation in Côte d'Ivoire, it would therefore be more judicious to collect seeds of $P$. erinaceus in the two most diverse sites, which would contain individuals from all three genetic groups, namely Moyenne Marahoué and Yalo.

\section{Structure of genetic diversity in Pterocarpus erinaceus}

The coefficient of differentiation among sites of $P$. erinaceus is 0.118 , indicating that about $11 \%$ of the total genetic diversity is expressed by allelic frequency variations among sites. Analysis of the dendrogram shows that Kouassi-Ndawa (subSudanese savannah) and Ouariguié (Sudanese savannah) sites are the most genetically similar, they constitute group I, together with Kahanso (sub-Sudanese savannah) and Téguirdouo
(Sudanese savannah). Group II gathers trees of Moyenne Marahoué (Guinean savannah). Group III gathers trees of Yalo (Guinean savannah). The genetic structure of trees from different sites by the Bayesian method also revealed three distinct genetic groups. Group I consists of a mixture of trees from the six sites. Group II, which is more homogeneous, consists exclusively of trees from the Moyenne Marahoué site, while group III trees mainly come from Yalo. These observations agree with those obtained by Amri and Mamboya (2012) and Jyothi et al., (2015) in $P$. angolensis and $P$. santilanus respectively. The results of their work showed that the majority of the genetic variations observed in these species were found to be high within the sites and low among the sites.

The genetic distance matrix shows low values between 0.030 and 0.117 reflecting a genetic proximity between the sites studied. This result reinforces the idea that the $P$. erinaceus sites present in Côte d'Ivoire belong to a common ancestral genetic pool. This level of diversity and this genetic structure could be essentially the result of the evolutionary history of the species and the action of human which has limited over time genes flow among populations of this species in Côte d'Ivoire. Our study shows that the sites of Moyenne Marahoué (group II) and Yalo (group III) are quite diverse. In addition, these two populations jointly host group I genotypes. Moreover, Moyenne Marahoué contains genotypes characteristic of group II and Yalo contains the genotypes characteristic of group III. They are therefore representative of the three determined genetic groups. It therefore appears necessary to put in place effective protection measures at these two sites in order to guarantee the conservation of the genetic diversity of $P$. erinaceus present. In-situ conservation plan ensuring the presence of a significant gene flow will make it possible to maintain most of the genetic variation of the species within these two populations.

\section{Conclusion}

The present study enabled the genetic characterization of $P$. erinaceus in six sites of Côte d'Ivoire. These results constitute an indispensable tool for any decision for sustainable management of the species gene pools. The RAPD markers showed a high level of polymorphism. Thus, these 
markers are useful for the analysis of the genetic diversity of the species. Genetic diversity assessed at three structuring levels revealed that it was more important within sites than among savannahs and sites. The conservation of the species must prioritize the collection of a maximum number of individuals within Moyenne Marahoué (group II) and Yalo (group III). It is therefore necessary to strengthen in-situ protection measures in these sites dedicated to biodiversity conservation in order to guarantee the preservation of the genetic diversity of $P$. erinaceus.

\section{Conflict of interest statement}

Authors declare that they have no conflict of interest.

\section{Acknowledgement}

This work was carried out as part of a single doctoral thesis. The authors thank the Société de Développement des Forêts (SODEFOR) for the access permits to the sites. Goba Koudougnon Alice particularly thanks the Programme d'Appui Stratégique à la Recherche Scientifique (PASRES) and the Instutite Pasteur in Côte d'Ivoire.

\section{References}

Adjonou, K., Houetchegnon, T., Rabiou, H., Segla, K.N., Abotsi, K.E., Johnson, B.N., Alaba, P., Ouinsavi, C.A.I.N., Quashie, A.M.L., Kokutse, A.D., Mahamane, A., Kokou, K., 2019. Challenges of conservation and sustainable management of african rosewood (Pterocarpus erinaceus) in West Africa. Nat. Resour Manage. Biol. Sci. Consulted on 10/20/2019.

Amri, E., Mamboya, F., 2012. Genetic diversity in Pterocarpus angolensis populations detected by random amplified polymorphic DNA markers. Int. J. Plant Breed. Gen. 6, 105-114.

Amusa, O., Adesoye, A., Ogunkanmi, A., Omoche, O., Olowe, O., Akinyosoye, S., Omodele, T., 2014. Genetic diversity of Parkia biglobosa from different agroecological zones of Nigeria using RAPD markers. Int. J. Biodivers. 2014, 1-6.

Arbonnier, M., 2004. Trees, shrubs and lianas of West African dry zones. Cirad, Margraf, MNHN, 574p.

Azmat, M.A., Khan, I.A., Cheema, H.M.N.,
Rajwana, I.A., Khan, A.S., Khan, A.A., 2012. Extraction of DNA suitable for PCR applications from mature leaves of Mangifera indica L. J. Zhejiang University-SCIENCE B (Biomed. Biotechnol.), 13 (4), 239-243.

Bureau National d'Etudes Techniques et de Développement (BNETD), 2015. Gestion durable des ressources forestières. Rapport pour les Etats généraux de la forêt, de la faune et des ressources en eau de Côte d'Ivoire, 89p.

Chaudhari, C., Jha, S., Dhaka, R.K., Parekh, V., Sankanur, M., Prajapat, P., Thakur, S., 2018. Genetic diversity analysis of teak in South Gujarat by RAPD marker. Int. J. Chem. Stud. 6(6), 260-267.

Convention on International Trade in Endangered Species (CITES), 2015. Analyse du commerce international de Pterocarpus erinaceus et ses conséquences en Afrique de l'ouest. Document d'information, Vingt-deuxième réunion du comité des plantes à Tbilissi (Géorgie), (19-23 octobre 2015), 35p.

Convention on International Trade in Endangered Species (CITES), 2017. CoP17 Information Paper - Global status of Dalbergia and Pterocarpus rosewood producing species in trade. 17th conference of the parties Johannesburg (24 september -5 october 2016) $246 \mathrm{p}$.

Dedehou, V.F.G.N., Olounladé, P.A., Alowanou, G.G., Azando, E.V.B., Hounzangbé-Adoté S., 2016. A review on medicinal plants of Parkia biglobosa (Mimosaceae-Fabaceae) and Pterocarpus erinaceus (LeguminosaePapilionoidea). J. Mech. Phys. Solids, 4 (6), 132-137.

Delos-Reyes, T.A.M., Magpantay, D.G., Cagalawan, A.G., Lapis, A.B., Calinawan, N.M., 2016. Assessment of genetic diversity of Narra (Pterocarpus indicus Willd.) populations from various seed Sources in the Philippines using RAPD. J. Environ. Sci. Manage. 192, 54-63.

Diniz-Filho, J.A.F., De Campos-Telles, M.P., 2002. Spatial autocorrelation analysis and the identification of operational units for conservation in continuous populations. Conserv. Biol. 16(4), 924-935.

Doyle, J.J., Doyle, J.L., 1987. A rapid DNA isolation procedure for small quantities of fresh leaf tissue. Phytochem. Bull. 19, 11-15.

Dumenu, W.K., 2019. Assessing the impact of felling/export ban and CITES designation on 
exploitation of African rosewood (Pterocarpus erinaceus). Biol. Conserv. 236(2019), 124-133.

Evanno, G., Regnaut, S., Goudet, J., 2005. Detecting the number of clusters of individuals using the software STRUCTURE : a simulation study. Mol. Ecol. 14, 2611-2620.

FAO, 2002. Note thématique sur les Ressources Génétiques Forestières. Situation des ressources génétiques forestières de Côte d'Ivoire (zone de savanes). 47p.

Felsentein, J., 2004. Inferring phylogenies. Simauer Ass. 664p.

Fontaine, C., Lovett, P.N., Sanou, H., Maley, J., Bouvet, J.M., 2004. Genetic diversity of the shea tree (Vitellaria paradoxa C.F. Gaertn), detected by RAPD and chloroplast microsatellite markers. Heredity. 93, 639-648.

Indu, B.K., Mohonty, S.K., Bhat, S., Swamy, M.K., Anuradha, M., 2019. Genetic diversity and conservation of Pterocarpus santalinus L.f. through molecular approaches. In : Pullaiah, T., Balasubramanya, S., Anuradha, M., (eds) Red Sanders: Silviculture and Conservation. Springer, Singapore. Pp. 173-187.

Jena, S., Sahoo, P., Mohanty, S., Das, A.B., 2004. Identification of RAPD markers, in situ DNA content and structural chromosomal diversity in some legumes of the mangrove flora of Orissa. Genetica. 122, 217-226.

Jyothi, C.J., Chandrashekar, R., Lakshmi, N.B., 2015. Analysis of genetic diversity in the populations of Pterocarpus santalinus detected by random amplified polymorphic (RAPD) DNA markers. J. Pharma. Biol. 5(1), 1-6.

Meirmans, P.G., 2006. Using the AMOVA framework to estimate a standardized genetic differentiation measure. Evolution. 60, 23992402.

Ministère des Eaux et Forêts (MINEF), 2013. Décret $\mathrm{n}^{\circ} 2013-508$ du 25 juillet 2013 portant interdiction de l'exploitation, de la coupe, du transport, de la commercialisation et de l'exportation de Pterocarpus spp appelé communément « bois de vêne ». J. Officiel Répub. Côte d'Ivoire, 22 août 2013 : 532-533.

Ministère des Eaux et Forêts (MINEF), 2018. Politique nationale de préservation, de réhabilitation et d'extension des forêts de Côte d'Ivoire - PNPREF, 24p.

Ministère de l'Environnement et du Développement Durable (MEDD), 2016. Plan
d'Investissement Forestier de Côte d'Ivoire DRAFT FINAL. Côte d'Ivoire, Ministère de l'Environnement et du Développement Durable, 85p.

Nei, M., 1972. Genetic distance between populations. Am. Nat. 106, 283-292.

Nei, M., 1987. Molecular Evolutionary Genetics. Columbia University Press, New York, 512p.

ONU, 2014. Rapport final du Groupe d'experts sur la Côte d'Ivoire établi en application du paragraphe 19 de la résolution 2101 (2013) du Conseil de sécurité (S/2014/266, 14th April 2014).

Ouédraogo, N., Hay, A.E., Ouédraogo, J.C.W., Sawadogo, W.R., Tibiri, A., Lompo, M., Nikiema, J.B., Koudou, J., Dijoux-Franca, M.G., Guissou, I.P., 2017. Biological and phytochemical investigations of extracts from Pterocarpus erinaceus Poir. (Fabaceae) root barks. Afr. J. Trad. Complem. Altern. Med. 14(1), 187-195.

Peakall, R., Smouse, P.E., 2012. GenAlEx 6.5: genetic analysis in Excel. Population genetic software for teaching and research-an update. Bioinformatics. 28, 2537-2539.

Phuong, T.M.T., Thu, H.T.T., Quang, T.H., 2019. Analysis of genetic diversity in $\mathrm{Pa} C o$ pine (Pinus kwangtungensis Chun ex Tsiang) using RAPD and ISSR markers. Viet. J. Sci. Techn. Eng. 62(1), 62-68.

Segla, K.N., Adjonou, K., Radji, A.R., Kokutse, A.D., Kokou, K., Rabiou, H., Kamana, P., Bationo, B.A., Mahamane, A., 2015. Importance socio-économique de Pterocarpus erinaceus Poir. au Togo. Eur. Sci. J. 11(23), 1857-7881.

Semagn, K., Bjornstad, A., Ndjiondjop, M.N., 2006. Principles, requirements and prospects of genetic mapping in plants. Afr. J. Biotechnol. 5(25), 2569-2587.

Silué, N., Fofana, J.I., Silue, S., Diarrassouba, N., Kouassi, A.F., Kouakou, K.K., 2014. Identification des espèces ligneuses utilisées dans l'alimentation des bovins dans la région du Poro (nord de la Côte d'Ivoire). Agron. Afr. 26(3), 217-229.

Sneath, P.H.A., Sokal, R.R., 1973. Numerical taxonomy: the principles and practice of numerical classification. San Francisco: Freeman, W.H. 573 p.

Song, Z.P., Li, B., Chen, J.K., Lu, B.R., 2005. Genetic diversity and conservation of common 
wild rice (Oryza rufipogon) in China. Plant Species Biol. 20, 83-92.

Sourou, K.B.N., 2017. Importance socioéconomique et caractérisation structurale, morphologique et génétique moléculaire de Haematostaphis barteri Hook F. (prune rouge) au Bénin. Thèse de Doctorat Unique, Université de Parakou, Ecole Doctorale des Sciences Agronomiques et de l'Eau, Bénin, 147p.

Sulistyawati, P., Widyatmoko, A.Y.P.B.C., 2017.
Genetic diversity in Kayu merah (Pterocarpus indicus Willd) populations using random amplified polymorphism DNA marker. J. For Plant Breed. 11(1), 67-76.

Watts, P.C., Kemp, S.J., Saccheri, I.J., Thompson, D.J., 2005. Conservation implications of genetic variation between spatially and temporally distinct colonies of the endangered damselfly Coenagrion mercuriale. Ecol. Entomol. 30, 541-547.

\section{How to cite this article:}

Goba, K. A. E., Kouonon, L. C., Koffi, K. G., Koffi, A., Tre, B. I. G., Sie, R. S., 2020. Molecular characterization of Pterocarpus erinaceus POIR. (Fabaceae) of Côte d'Ivoire using RAPD markers. Int. J. Curr. Res. Biosci. Plant Biol. 7(5), 13-23. doi: https://doi.org/10.20546/ijcrbp.2020.705.003 